Article

\title{
Permaculture: Challenges and Benefits in Improving Rural Livelihoods in South Africa and Zimbabwe
}

\author{
Zahra Didarali ${ }^{*}+\left(\mathbb{D}\right.$ and James Gambiza ${ }^{+}$ \\ Department of Environmental Science, Rhodes University, Grahamstown 6139, South Africa; j.gambiza@ru.ac.za \\ * Correspondence: zdidarali@gmail.com; Tel.: +27-46-603-7002 \\ + These authors contributed equally to this work.
}

Received: 16 February 2019; Accepted: 4 April 2019; Published: 12 April 2019

\begin{abstract}
Feeding a growing global population using conventional agricultural practices is leading to adverse environmental impacts. There is a call for alternative forms of agriculture that address social, economic, and environmental aspects of sustainability. Permaculture is a holistic design framework that incorporates sustainable agricultural practices, potentially improving livelihoods. This study looked at the challenges and benefits of permaculture in improving rural livelihoods in Zimbabwe and South Africa. We used semi-structured interviews to collect data. Permaculture contributed over $40 \%$ to total income for participants in both countries. However, permaculture was not the dominant source of income and periodically straddled multiple livelihood strategies. The main benefits of permaculture were identified as improved human health, increased resilience to environmental changes, and reduction of input costs. The key challenges included high labour input, infestation of pests and diseases, and lack of knowledge on permaculture practices. Although permaculture presents significant challenges, its integration with other forms of sustainable agricultural practices can contribute to improved rural livelihoods.
\end{abstract}

Keywords: agriculture; agroecology; livelihoods; permaculture

\section{Introduction}

Agriculture is one of the most important human endeavours [1,2]. It serves as the main source of food, which is crucial for the survival of the human race. Today, however, the global food system is at a crossroads [3]. Although agricultural systems supply large quantities of food through intensification, their sustainability is questionable [4]. As climate change continues to dominate scientific discourse, the expectation that agricultural systems will need to adapt is widely accepted $[5,6]$. Resource intensive agricultural practices have catastrophic impacts on the environment and societies at large [4-6].

A transition to sustainable agricultural systems is required for social and economic equity, food security, conservation of biodiversity, and provision of ecosystem services [6]. Permaculture is an approach that could contribute to the sustainability of social and ecological systems [5]. Although it is difficult to define permaculture, it can be understood in terms of four characteristics that are interrelated [7].

The first emphasizes the potential of synergistic effects on ecosystem health and human well-being. At the same time, permaculture presents a model of change that stresses the importance of individuals' and local communities' ability to act [8]. Second, permaculture draws on systems thinking and ecological principles, which offer different approaches for analysis, and relevant practices that are unique to each site. Third, permaculture is described as a framework that aims to optimize ecological systems. Finally, fourth, due to its focus on individual responsibility and small-scale solutions, permaculture is less institutionalized than other agricultural approaches [8]. For the purpose of this study, the definition of permaculture we adopted focuses on the first and third characteristics, which 
emphasize synergistic effects on ecosystem health and human well-being. Given the focus on rural livelihoods in this study, the following definition of permaculture is used: Permaculture is a design system that uses ecological management practices and locally adaptive solutions for sustainability in all aspects of human endeavour. Such practices aim to optimise the interactions in the soil-plant system for an efficient use of their ecological functions and ecosystem services, while promoting diverse, resilient, and regenerative agricultural systems [9].

While permaculture is transdisciplinary in its nature, it places emphasis on ecosystem health [10]. What distinguishes permaculture from other approaches is its comprehensive design process. Each site, whether a garden, farm, school, or household, has a unique set of elements and design considerations [9]. Its approach to production focuses on multi-functionality and diversity through the use of integrated water management, land use diversification, polycultures, and perennial cropping [8]. Twelve principles (Table A1) and three ethics, care for people, care for earth, and fair share, inform the practice of permaculture [11]. As proposed by these ethics, permaculture is the design of sustainable socio-ecological land use systems. Permaculture recognizes the interdependence of land use systems and social systems [12].

The design principles that inform permaculture draw on the concept of systems thinking [13]. Examples of systems thinking include ecosystems in which soil, water, animals, plants, and air all work together. The principles are short statements that give a wide range of options for action when dealing with complex systems. Krebs and Bach (Table A1) give a summary of the twelve principles of permaculture with broad examples.

There is limited information on the benefits and challenges of permaculture [8]. However, it has been argued that the application of permaculture is likely to succeed in countries of the Global South [14-16]. This has been attributed to the extensive use of traditional agricultural practices and labour-intensive practices in many countries in Southern Africa [14]. Permaculture also has the potential to galvanize action towards the achievement of multiple sustainable development goals (SDGs) [17]. Some of these include zero hunger, good health and well-being, and life on land. The uptake of permaculture by smallholder farmers in Southern Africa is, however, slow [18]. Therefore, more research is required to assess the benefits and constraints associated with the practice.

This study attempted to answer the following two questions. First, what is the effect of permaculture on rural livelihoods in Southern Africa? Second, what are the enablers and barriers to the adoption of permaculture in Southern Africa? Semi-structured interviews were used to collect data. We used both quantitative and qualitative methods to analyze the data.

\section{Study Area}

This study was conducted in rural parts of South Africa and Zimbabwe. The study areas were Middledrift and Ngqeleni, towns in South Africa, and the Chimanimani district in Zimbabwe. The study areas were chosen as they represent the major agro-ecological regions of both countries.

Middledrift is a small town located $90 \mathrm{~km}$ north-west of East London and is situated in the Raymond Mhlaba Municipality in the Amathole District, Eastern Cape (EC), with a population of 20,600 individuals. The region has a mild and temperate climate and receives $412 \mathrm{~mm}$ of rainfall per year [19]. It hosts a range of vegetation types including thornveld, semi-arid Karoo, thicket areas and succulent plants. Communal farming is a dominant practice where vegetables, maize, and livestock are the main agricultural commodities [20]. Each household has access to 0.08 ha of cropland, comprising of large crop fields as well as small vegetable plots. Key contributors to employment in the district include trade (25.5\%) and agriculture (15.1\%) [20].

Ngqeleni village is $40 \mathrm{~km}$ north-west of Coffee Bay and is situated in the OR Tambo District, EC, with a population of 2600 individuals. The region has a warm temperate climate and receives $652 \mathrm{~mm}$ of rainfall per year [21]. The region hosts a diversity of vegetation from bushveld to thicket forests. Agriculture forms the basis of primary activities and is mainly subsistence. Vegetables, maize, 
and livestock are the main agricultural commodities produced in the region [22]. Key contributors to employment in the district include community services (34\%), trade (24\%), and agriculture (4\%).

Chimanimani is located in Chimanimani district, Manicaland Province in south-eastern Zimbabwe, with a population of 2700 individuals. The south-western parts of the district fall under the semi-arid agro-ecological zone with a harsh environment due to variable annual rainfall ranging from 450-800 mm [23]. Millet varieties, sorghum, and drought resistant maize are mostly grown in this area, where subsistence farming is the major land use.

\subsection{Data Collection}

This study adopted a mixed methods approach, which combines philosophy, research design, and orientation methods [24]. It is a procedure for collecting, analyzing, and mixing both quantitative and qualitative research methods within a study. The use of such an approach allowed for a greater understanding of research problems, in comparison with the use of only one approach [24].

We interviewed 94 key informants using semi-structured interviews in June 2018. In South Africa, 44 interviews were conducted in Ngeqeleni $(n=22)$ and Middledrift $(n=22)$ in EC. In Zimbabwe, 50 interviews were carried out in the Chimanimani district. The sample size was limited to 94 respondents due to budget constraints and a limited number of people who had received permaculture training.

Permaculture practitioners were selected as respondents, given the nature of this study. The key informants had received some form of permaculture training, either formally (certified) or informally (non-certified). These key respondents were identified through the help of the two following organisations: Hope Permaculture and Chikukwa Ecological Land Use Community Trust (CELUCT). Hope Permaculture and CELUCT are organisations and training centres that support community-based permaculture projects in South Africa and Zimbabwe, respectively. In addition to identifying key informants, both organizations aided in selecting enumerators from the community, whom we trained on how to conduct the interviews.

Before conducting interviews, all participants signed a consent form which assured anonymity, the right of withdrawal, and confidentiality of their information. Ethics approval was obtained from the Environmental Science Department of Rhodes University and the signed document was in accordance with the Rhodes Ethics guidelines [25]. We assumed that the respondents gave honest information.

The semi-structured questionnaire consisted of five sections. The first section asked questions pertaining to demographic characteristics such as age, gender, and education. The second section contained questions regarding permaculture training and required information on the kind of training received (i.e., formal or informal). This was followed by a section on livelihood activities, which gathered information on income before and after practising permaculture and other livelihood strategies. In addition to average income earned from other activities, respondents reported how much they earned or saved from practising permaculture. Respondents were also asked to report how permaculture changed their income. This was grouped into the following categories: improved substantially, moderately, slightly, no change, or decreased. The next section required descriptions on the crops grown and inputs used before and after practising permaculture. It also included questions on place of practice, hours of labour, and the size of the cultivated area.

Crops were grouped into cereals, vegetables, legumes, tubers, and fruits. The average number of crop varieties grown in each category was calculated. The final section contained open-ended questions that allowed respondents to share their views on the challenges and benefits associated with permaculture.

\subsection{Data Analysis}

In addition to standard descriptive procedures, all statistical tests were performed using RStudio version 1.0.153 [26]. A chi-square test was used to test for association of categorical data, such as change in income. 
Quantitative data, such as income, labour hours, and size of cultivated area, were first tested for normality using the Shapiro test. Non-parametric tests were used for non-normal data. Wilcox signed-rank tests were used to test for differences in mean income and the size of cultivated areas between South Africa and Zimbabwe. Furthermore, a paired Wilcoxon signed-rank test compared the average number of crop varieties grown before and after permaculture.

Exploratory factor analysis (EFA) was performed to identify latent factors that were explained by the measured variables. It is a multivariate analysis technique that models underlying relationships among measured variables [27]. The optimum number of factors was determined by analysing the scree plots (Figures A1 and A2) [28]. The point at which the steep curve flattened was an indication of the optimal number of factors required. The variables used for EFA included age, gender, education, type of permaculture training, average income, proportion of income contributed by permaculture, size of cultivated area, and hours of labour.

Content analysis was used to analyse the challenges and benefits associated with permaculture. Moreover, recurring themes were assessed that emerged from the participants' responses. These themes were grouped into categories. The chi-square test was used to test for associations of the type of challenge or benefit mentioned.

\section{Results}

\subsection{Demographics of Permaculture Participants}

In South Africa, 53\% of the respondents were female, whereas there was an equal representation of male and female respondents in Zimbabwe (Table 1). The majority of respondents from both countries were middle-aged, ranging from 35-54 years old.

Table 1. Age and gender characteristics of South African and Zimbabwean respondents.

\begin{tabular}{lcc}
\hline & South Africa $(n=44)$ & Zimbabwe $(n=50)$ \\
\hline Gender & 25 & 25 \\
Number of Females & 15 & 25 \\
Number of Males & 4 & \\
Prefer not to say & & \\
\hline Age (years) & 3 & 0 \\
18-24 & 7 & 6 \\
$24-34$ & 12 & 13 \\
$35-44$ & 13 & 19 \\
$45-54$ & 7 & 4 \\
$55-64$ & 2 & 8 \\
$>65$ & & \\
\hline
\end{tabular}

Most respondents in Zimbabwe received high school education, whereas the majority of respondents in South Africa attended a technical college (Table 2). All participants received some form of permaculture training, either certified or non-certified. In both South Africa (63\%) and Zimbabwe $(60 \%)$, the majority of the participants received formal (certified) training, whereas almost $40 \%$ of respondents from both countries learned informally through social/peer learning.

Table 2. Level of education and permaculture training of South African and Zimbabwean respondents.

\begin{tabular}{lcc}
\hline & South Africa $(\boldsymbol{n = 4 4 )}$ & Zimbabwe $(\boldsymbol{n}=\mathbf{5 0})$ \\
\hline Level of education & 4 & 18 \\
Primary School & 15 & 31 \\
High School & 17 & 1 \\
Some College & 8 & 0 \\
Bachelor's Degree & & \\
\hline Permaculture training received & 28 & 30 \\
Formal (certified) & 26 & 20 \\
Informal (non-certified) & & \\
\hline
\end{tabular}




\subsection{Years Spent Practising Permaculture}

Zimbabwean practitioners had 1.75 times more years of experience than South African practitioners. There were highly significant differences in the duration of practice between Zimbabwean and South African respondents $(W=360.5, p<0.001)$. Respondents in South Africa were fairly new permaculture practitioners, with $7.6 \pm 7.8$ years of experience. On the other hand, Zimbabwean practitioners had $13.3 \pm 8.0$ years of experience.

\subsection{Place of Permaculture Practice}

Respondents practised permaculture in three different places: farms, home gardens, and school gardens (Table 3). Permaculture was most commonly practised on home gardens in South Africa (61\%) and Zimbabwe (46\%). An association was found between the place of practice $\left(\chi^{2}(5)=16.05, p<0.01\right)$ and country. While a small percentage of South African respondents $(12 \%)$ practised permaculture on school gardens as well as on municipal land, no Zimbabwean respondents were found to practise permaculture in these areas. A significantly higher proportion of Zimbabwean respondents (34\%) than South African respondents (9\%) practised permaculture on both their home gardens and farms. Those that practiced permaculture on farms did so for both home and commercial use.

Table 3. Place of permaculture practice across South African and Zimbabwean respondents, with chi-squared test values.

\begin{tabular}{lccc}
\hline & South Africa $(\boldsymbol{n}=\mathbf{4 4})$ & Zimbabwe $(\boldsymbol{n}=\mathbf{5 0 )}$ & $\chi^{\mathbf{2}}$ \\
\hline Home garden & 27 & 23 & 0.32 \\
Farm & 6 & 10 & 1 \\
Home garden and farm & 4 & 17 & $8.05^{* *}$ \\
School garden & 3 & 0 & 3 \\
Home and school garden & 2 & 0 & 2 \\
Municipality land & 2 & 0 & 2 \\
$\chi^{2}$ & $64.81^{* * *}$ & $60.16^{* * *}$ & \\
\hline \multicolumn{4}{c}{$p<0.01^{* * *} p<0.001}$.
\end{tabular}

\subsection{Size of Area Cultivated Using Permaculture Practices}

A significant difference in the average size of cultivated area between the two countries was found $(W=827, p<0.05)$. The smallest cultivated area was found to be $12 \mathrm{~m}^{2}$ in South Africa and $42 \mathrm{~m}^{2}$ in Zimbabwe (Figure 1). In contrast, the largest areas were $50,000 \mathrm{~m}^{2}$ and $30,000 \mathrm{~m}^{2}$ for South Africa and Zimbabwe, respectively.

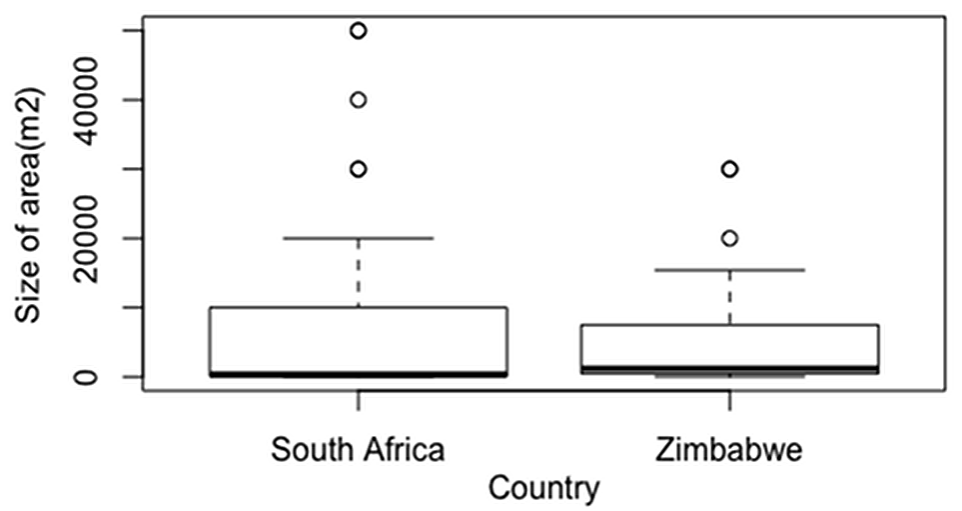

Figure 1. Boxplot showing the size of area $\left(\mathrm{m}^{2}\right)$ where permaculture was practised for South African and Zimbabwean respondents. 


\subsection{Hours of Labour Practising Permaculture}

A highly significant difference was found in the number of hours spent practising permaculture between the two countries $(W=946, p<0.001$ ). On average, South African practitioners put in $20.97 \pm 30.3 \mathrm{~h}$ of labour per week. On the other hand, Zimbabwean practitioners put in $18.43 \pm 13.4 \mathrm{~h}$ per week.

\subsection{Income of Participants}

The average income of South African participants was $\$ 300 \pm \$ 241$ and $\$ 121 \pm \$ 102$ for Zimbabwean participants. The exchange rate was USA \$1 to R14.51 South African Rand the time of the study. A Wilcoxon test revealed a highly significant difference in income earned by the participants of the two countries $(W=1660, p<0.001$ ). South Africans earned 2.4 times more than Zimbabweans. On average, permaculture contributed $47 \%$ and $45 \%$ towards total income for South African and Zimbabwean practitioners, respectively. There was no significant difference in the mean proportion of income contributed by permaculture between the two countries $(W=1073.5, p>0.05)$.

Significant associations were found in income change categories after applying permaculture between South Africa and Zimbabwe $\left(\chi^{2}(3)=9.17, p<0.05\right)$. In South Africa (35\%) and Zimbabwe $(50 \%)$, the majority of respondents noted that their income improved slightly. Highly significant associations were found in income change categories in Zimbabwe $\left(\chi^{2}(3)=22.48, p<0.001\right)$. Permaculture substantially improved the income of $18 \%$ of the respondents (Figure 2). No significant associations were found between the income change categories within South Africa $\left(\chi^{2}(3)=4.55\right.$, $p>0.05)$. Individual counts and chi-squared values are given in Table A2.

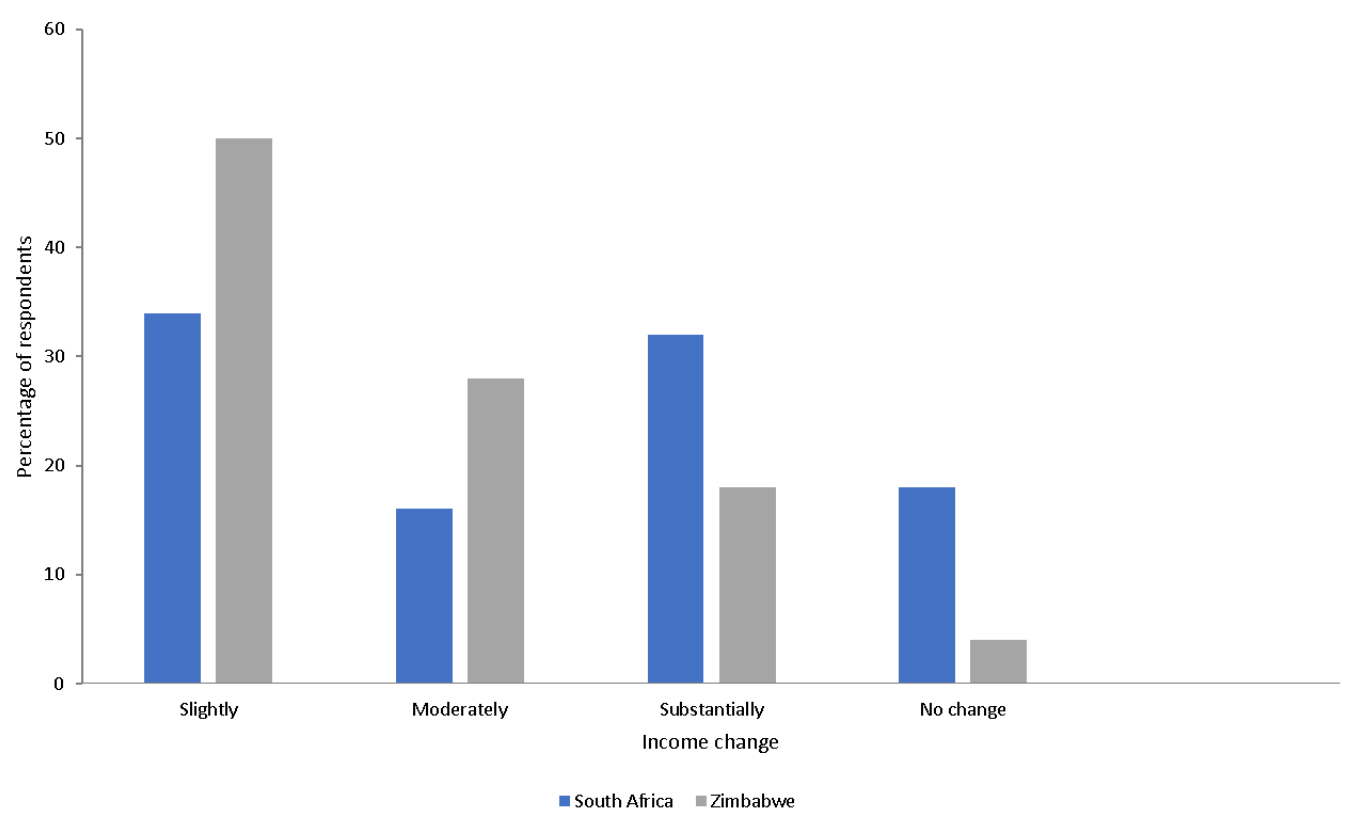

Figure 2. Change in income after practising permaculture for South African $(n=44)$ and Zimbabwean $(n=50)$ respondents.

\subsection{Livelihood Strategies}

In addition to permaculture, there were two main sources of income, income generated from conventional agricultural practices and non-agricultural related practices - from activities such as knitting, building, and formal employment (Figure 3). It was apparent that respondents from both countries did not rely on permaculture as their dominant source of income. Of the 44 South African participants, only four relied on permaculture as their main source of income. Of the 50 Zimbabwean participants, only one relied on permaculture as their dominant source of income. The most common 
source of income for South African respondents was teaching. Whereas Zimbabwean respondents relied heavily on conventional agriculture and vending as additional sources of income.

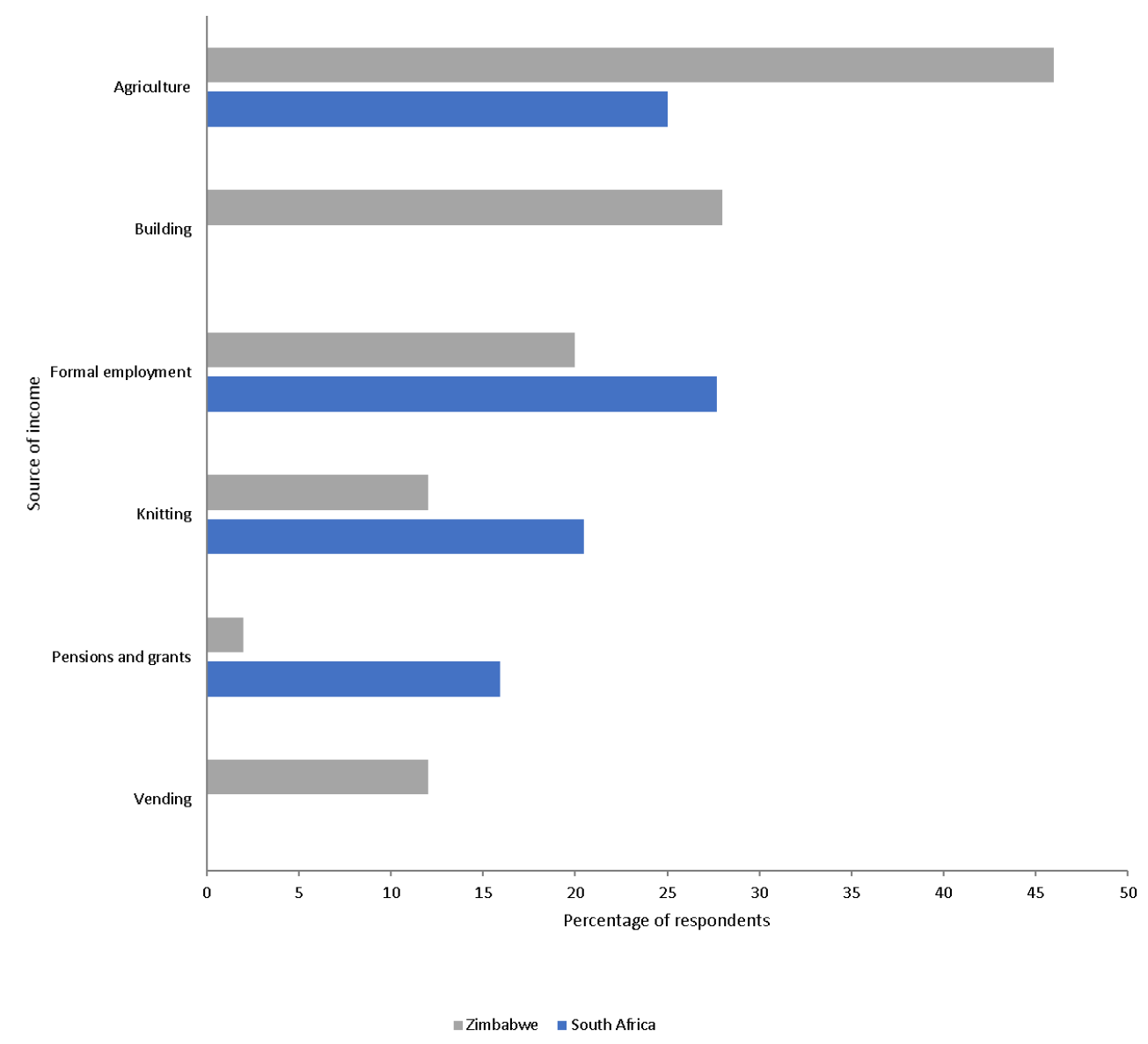

Figure 3. Most common sources of income for South African and Zimbabwean respondents.

\subsection{Factor Analysis of Socio-Economic Variables}

\subsubsection{Correlation of Different Variables for South African Permaculture Practitioners}

A strong correlation between hours spent practising permaculture and income was identified using EFA (Figure 4). Participants that put in more labour hours and received formal permaculture training gained more economic benefits from permaculture than those who put in less hours and received informal training. The duration of practice was not correlated with any items. Based on the variables that loaded onto Factor 1 (MR1), the factor was identified as the economic returns from permaculture and accounted for $51 \%$ of the variance.

A realistic hidden variable could not be identified for Factor 2. Age had a strong negative relationship, but no meaningful associations could be drawn from the remaining variables, which all had weak relationships.

\subsubsection{Correlation of Different Variables for Zimbabwean Permaculture Practitioners}

Similar to South Africa, Factor 1 was also identified as economic returns from permaculture, as it loaded highly with size of area, labour hours and income (Figure 4). Those that cultivated on large areas required additional hours of labour to achieve a positive change in income. Factor 1 accounted for $18 \%$ of the variance. 
Factor 2 was identified as experience in permaculture as it loaded highly with age and duration of practice. This indicated that older practitioners had more experience. Factor 2 accounted for $13 \%$ of the variation.

Factor 3 indicated that the proportion of income was an independent variable and accounted for $11 \%$ of the variance. Lastly, Factor 4 accounted for $11 \%$ of the variance and indicated that more males than females received formal permaculture training.
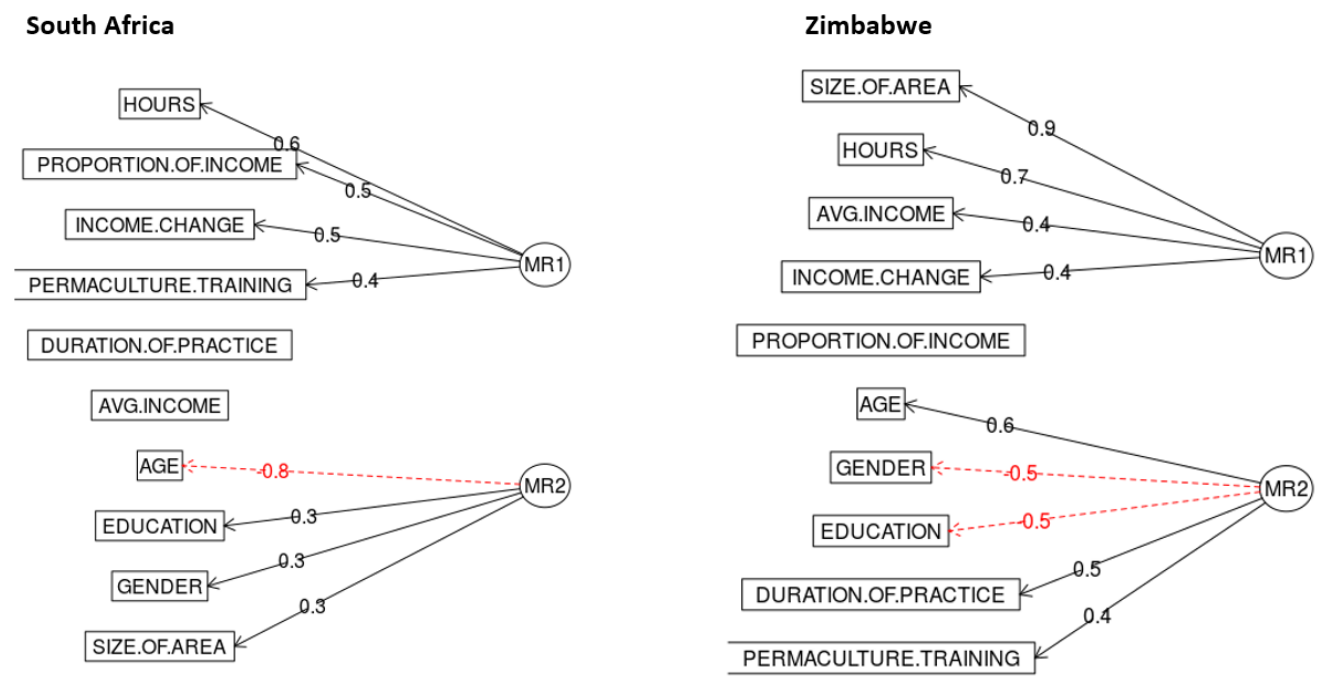

Figure 4. Factor analysis showing the correlation of different variables for South Africa and Zimbabwe.

\subsection{Agricultural Inputs Before and After Practising Permaculture}

In both South Africa and Zimbabwe, over $70 \%$ of the participants shifted from using chemical to organic fertilizers (Figure 5). For participants that also employed conventional agricultural practices, chemicals were still used. Moreover, many South African (70\%) and Zimbabwean (50\%) participants shifted from using chemical to organic pesticides. Participants in both countries also shifted from using hybrid seeds to non-hybrid seeds, that they often saved.

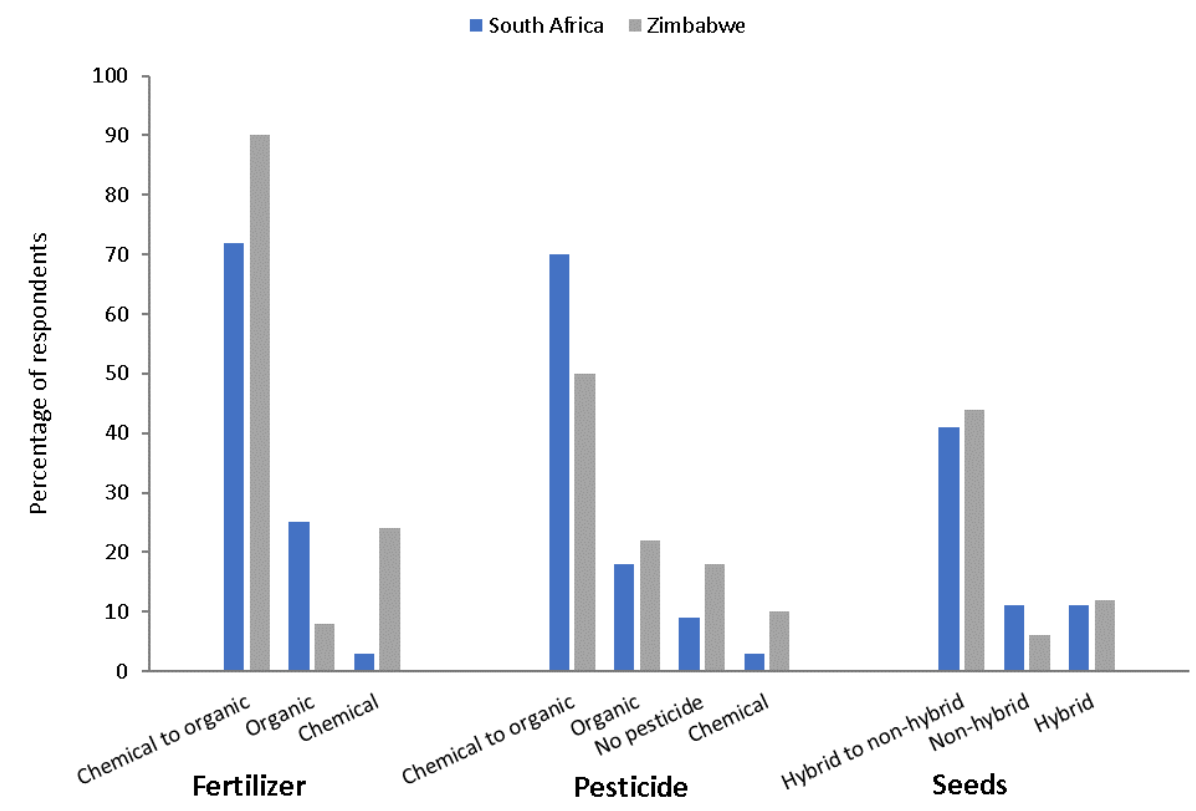

Figure 5. Agriculture inputs used by South African $(n=44)$ and Zimbabwean respondents $(n=50)$ after employing permaculture practices. 


\subsection{Crop Diversity After Practising Permaculture}

In South Africa, participants grew eight different types of vegetables, whereas in Zimbabwe, six different vegetables were grown (Figure 6). Zimbabwean practitioners grew five different varieties of legumes compared with South African practitioners, who grew three different varieties of legumes. Respondents in both countries grew the same types of cereals, that is maize, millet and sorghum.

Highly significant differences were found in the average number of fruits $(V=325, p<0.001)$ and vegetables $(V=539, p<0.001)$ grown after practising permaculture in Zimbabwe. In South Africa, highly significant differences were also found between the average number of vegetables $(V=507$, $p<0.001)$ and fruits $(V=325, p<0.001)$ grown. In both countries, participants grew over twice the number of vegetables and nearly five times the number of fruits. Paired Wilcoxon values for all crop varieties are given in Table A3.

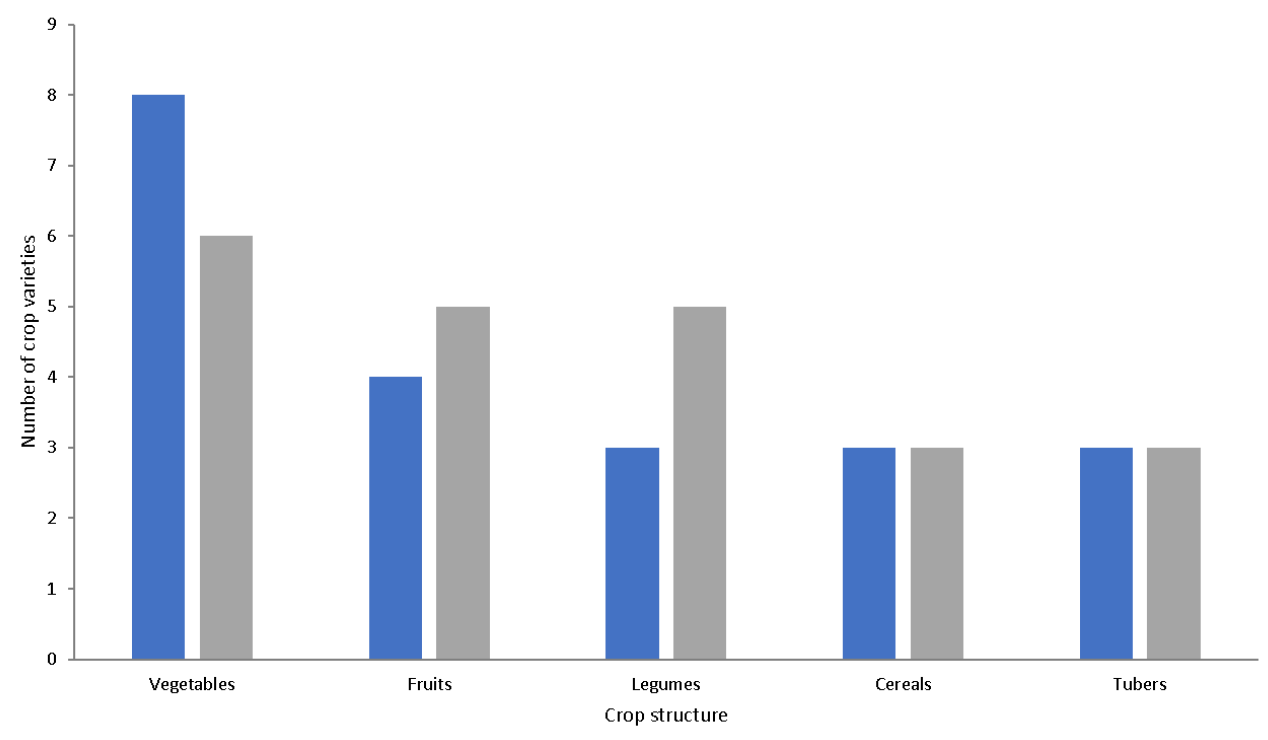

- South Africa $\quad$ Zimbabwe

Figure 6. Type and number of crop varieties grown by South African and Zimbabwean respondents.

\subsection{Benefits Associated with Permaculture Practices}

Perceived benefits of permaculture, among participants from South Africa and Zimbabwe, were grouped into three categories, as follows: quality of life, environmental, and economics, as illustrated in Table 4 . No associations were found between the type of benefits mentioned between the two countries $\left(\chi^{2}(6)=12.74, p>0.05\right)$. However, significant associations between the type of benefits mentioned were found within South Africa $\left(\chi^{2}(7)=38.09, p<0.001\right)$ and Zimbabwe $\left(\chi^{2}(7)=39.51, p<0.001\right)$. Few South African (14\%) and Zimbabwean (16\%) respondents viewed permaculture as an affordable practice. In contrast, over $65 \%$ of respondents from both countries reported feeling healthy because of eating more nutritious food.

With regards to environmental benefits, a higher proportion of South African (52.3\%) than Zimbabwean (16\%) respondents mentioned that permaculture fostered respect for nature and people $\left(\chi^{2}(1)=7.26, p<0.01\right)$. Economic benefits included the reduction of input costs, which created the opportunity to save money. Lastly, over $25 \%$ of respondents from both countries indicated higher yields as a benefit. 
Table 4. Benefits associated with permaculture for South African and Zimbabwean respondents.

\begin{tabular}{|c|c|c|c|c|c|}
\hline Theme & Sub-theme & Description & $\begin{array}{l}\text { South Africa } \\
\quad(n=44)\end{array}$ & $\begin{array}{c}\text { Zimbabwe } \\
(n=50)\end{array}$ & $x^{2}$ \\
\hline \multirow{3}{*}{ Quality of life } & & $\begin{array}{l}\text { Eating more diverse foods, } \\
\text { high nutritional intake }\end{array}$ & 39 & 34 & 0.34 \\
\hline & Food security & Access to a variety of foods & 27 & 27 & 0 \\
\hline & Well-being & Respect for nature and people & 23 & 8 & 7.26 ** \\
\hline \multirow{2}{*}{ Environmental } & \multirow{2}{*}{$\begin{array}{c}\text { Long term } \\
\text { sustainability }\end{array}$} & $\begin{array}{l}\text { Improves ability to address } \\
\text { environmental problems: } \\
\text { increases resilience }\end{array}$ & 33 & 33 & 0 \\
\hline & & $\begin{array}{l}\text { Use of local resources and } \\
\text { reduced dependence on } \\
\text { chemical input }\end{array}$ & 18 & 26 & 1.45 \\
\hline \multirow{4}{*}{ Economics } & \multirow{3}{*}{$\begin{array}{l}\text { Economic } \\
\text { returns }\end{array}$} & $\begin{array}{l}\text { Increased savings from } \\
\text { reduced input }\end{array}$ & 19 & 32 & 3.31 \\
\hline & & High yields & 11 & 14 & 0.36 \\
\hline & & Affordable & 6 & 7 & 0.08 \\
\hline & & $x^{2}$ & $38.09 * * *$ & $39.51^{* * *}$ & \\
\hline
\end{tabular}

\subsection{Challenges Associated with Permaculture Practices}

Challenges associated with permaculture were also grouped into three categories: education, environmental and economics, as illustrated in Table 5. Highly significant associations were found within the type of challenge between the two countries $\left(\chi^{2}(6)=24.47, p<0.001\right)$. A significantly higher proportion of South African (43\%) than Zimbabwean (6\%) respondents mentioned that they lacked knowledge on how to deal with problems using permaculture practices.

With regards to the environmental category, the biggest challenge faced by participants of South Africa (41\%) and Zimbabwe (52\%) was drought. From an economic point of view, over $30 \%$ of respondents from both countries were concerned about the inefficiencies linked to permaculture, such as it being a labour intensive practice. A higher proportion of South African $(25 \%)$ than Zimbabwean respondents (6\%) found low yield to be a challenge. Some participants in South Africa $(20 \%)$ and Zimbabwe (8\%) also mentioned that permaculture required high initial capital.

Table 5. Most frequently identified challenges faced by South African and Zimbabwean respondents.

\begin{tabular}{|c|c|c|c|c|c|}
\hline Theme & Sub-theme & Description & $\begin{array}{l}\text { South Africa } \\
\quad(n=44)\end{array}$ & $\begin{array}{c}\text { Zimbabwe } \\
(n=50)\end{array}$ & $\chi^{2}$ \\
\hline Education & $\begin{array}{l}\text { Knowledge } \\
\text { and research }\end{array}$ & $\begin{array}{l}\text { Lack of knowledge on how to } \\
\text { deal with challenges }\end{array}$ & 19 & 3 & $11.64^{* * *}$ \\
\hline \multirow[b]{2}{*}{ Environmental } & Climate & \multirow{2}{*}{$\begin{array}{l}\text { Drought } \\
\text { Poor management of diseases, } \\
\text { pest infestation }\end{array}$} & 18 & 26 & 1.45 \\
\hline & Pest & & 12 & 17 & 0.86 \\
\hline \multirow{5}{*}{ Economics } & $\begin{array}{l}\text { Economic } \\
\text { viability }\end{array}$ & $\begin{array}{l}\text { Requires extra land } \\
\text { (size limitation) }\end{array}$ & 15 & 7 & 2.9 \\
\hline & Inefficiency & $\begin{array}{l}\text { High labour, need for additional } \\
\text { source of income }\end{array}$ & 14 & 23 & 2.19 \\
\hline & \multirow{2}{*}{$\begin{array}{l}\text { Economic } \\
\text { returns }\end{array}$} & Less productive (yield) & 11 & 3 & $4.5^{*}$ \\
\hline & & Requires initial capital/input & 9 & 4 & 1.92 \\
\hline & & $\chi^{2}$ & 5.71 & $50^{* * *}$ & \\
\hline
\end{tabular}




\section{Discussion}

\subsection{Demographics of Participants}

An important aspect of permaculture is the ongoing acquisition of knowledge through peer learning. Permaculture principles include the built environment, health, economics and education, as ways of enhancing social systems that foster best ecological practices [12]. As shown in Table 2, knowledge on permaculture was acquired informally through social learning in both South Africa and Zimbabwe. Similar exposure of permaculture through informal training has also been observed in Malawi, where the majority of farmers received permaculture training informally [29]. Permaculture can therefore be effective at fostering the exchange of knowledge that combines traditional and scientific practices. A permaculture community project in Johannesburg showed that social learning enhanced human capital through skills development [22]. Many scholars have also recognized social learning as a means to enhance social-ecological systems resilience [22,30].

Conrad (2014) revealed in a study that practitioners who received formal training practised permaculture the longest [29]. This study found a similar correlation for Zimbabwean respondents as revealed in the EFA diagram (Figure 4). However, this could also be related to age, as Zimbabwean practitioners who received formal training were older.

\subsection{Years of Experience in Permaculture}

Permaculture systems are generally slower than modern conventional farming systems at developing and reaching full productivity, which speaks to the ninth permaculture principle, use of small and slow solutions [31]. In contrast, conventional farming techniques that involve the destruction of ecosystems by clearing land for monocrops to maximize production. Moreover, permaculture values the gradual process of strengthening ecosystems through diversification [12,32].

The years of experience is an important factor to consider in understanding the challenges and opportunities associated with permaculture. Realizing the benefits derived from permaculture may take a long time to be evident. South African participants were fairly new permaculture practitioners with about 7 years of experience compared with Zimbabwean's 13 years. The principle of small and slow solutions assumes that small-scale systems have the potential to be more intensive and productive, such as gardening for self-sufficiency [12]. The size of the cultivated area, therefore, becomes the next important factor to consider.

\subsection{Size of Area Cultivated Using Permaculture Practices}

Lowder et al. (2016) found that $72 \%$ of the world's agricultural land is cultivated by small family farms (less than 1 ha) [33]. Contrarily, farms ranging from 1-2 ha constitute only $12 \%$ of the world's agricultural land. While permaculture farms in developed countries, such as United States have large (600 ha) profitable areas of production, literature shows an inverse relationship between size and productivity $[33,34]$. Figure 4 revealed a similar relationship, as more hours of labour were required as size of land increased.

Similar relationships have been observed in Southern African countries, such as Zambia [35], where smaller farms were found to have higher land quality. It is therefore argued that permaculture may be better suited for developing countries, where small-scale farming is dominant. Permaculture may strengthen the viability and competitiveness of farming in rural areas, such as Zimbabwe and South Africa, where farm size is a limitation [34,35]. It is also necessary to investigate whether slow developing systems are economically viable.

Smaller farms and fields have more field edges, which have beneficial consequences as outlined in principle 11, use edges and value the marginal. Resources and functions of bordering ecosystems are present in edges, which maybe more productive and diverse. For example, in Germany, higher 
biodiversity, species richness, and abundance were found in areas with small scale agriculture in field edges, compared to the centres [36].

\subsection{Income of Participants}

Agriculture is the economic foundation of many developing countries, such as those in Southern Africa [37]. Agricultural practices should, therefore promote the well-being of farmers and profitable yields, as well as conserve the long-term productivity of land.

In both South Africa and Zimbabwe, permaculture contributed more than $45 \%$ of people's income. Although the adoption of permaculture practices improved participants' income, most used mixed livelihood strategies to supplement their income with other sources. Tererai (2012) found similar results in Southern Africa. In addition to permaculture, two main sources of income were identified, as follows: conventional agricultural and non-agricultural practices [38]. The extent of dependence on these sources varied between the two countries. Zimbabwean participants relied heavily on conventional agricultural practices to supplement their income. They mentioned the need to employ conventional farming techniques due to higher yields observed.

Participants also noted that farming allowed them to maximize productivity and economic returns. This has also been noted by Rodriguez et al. (2009) [39], who postulated that agroecological systems develop slower in comparison to conventional practices, taking some years to reach full profitability and productivity [40]. Some practitioners infer the potential economic viability of permaculture through increased system self-sufficiency, although no evidence is available [41]. However, an interesting observation for South Africa was that formal permaculture training, in particular, yielded better income returns per hours spent, as illustrated in Figure 4.

Identifying an agricultural system that is appropriate for Southern African countries, that not only has a neutral effect on ecological surroundings, but is simultaneously economically viable is necessary. Permaculture may promote economic viability, social well-being, and environmental preservation.

\subsection{Crop Diversity after Adoption of Permaculture}

Results showed that participants from both countries increased their variety of crops. Significantly more vegetables and perennial trees were grown. This is in line with permaculture literature, which places emphasis on growing perennial crops [42]. While perennials are valued for system efficiency and resilience, some species take longer to produce sufficient yields. Permaculture practices may therefore be less suited for individuals who rely on short term profits.

Similar to a United States assessment on permaculture systems, annual vegetables were found to be important to both countries for commercial purposes and for self-sustenance [11]. However, a small percentage of respondents across both countries decreased the number of cereals grown. Millet was the cereal most participants stopped growing after they adopted permaculture. Most participants continued to grow maize and sorghum. This can be attributed to the primary role maize plays as a staple food crop in South Africa and Zimbabwe [43]. This explains the reliance of practitioners on mixed annual and perennial cropping.

Crop diversity has several benefits. According to De Clerck et al. (2011) and Remans et al. (2011), increased crop diversity may improve functional diversity. Using and valuing diversity constitutes one of the twelve principles of permaculture (see Appendix A1) [44,45]. This is based on the fact that diversity enhances ecological and social resilience. Intercropping and agrobiodiversity can aid in managing crop diseases, lowering pest density, preventing soil erosion, and, thus, stabilizing production $[41,46]$. Given the value of diversified systems, permaculture could enhance the protection of ecosystem services.

Principle eight of permaculture, integrate rather than segregate, also values the diversity of plants and animals. Increasing trophic networks and habitat diversity leads to increased resilience of a system against changing climate or socio-economic perils. This has been noted in countries like Brazil and France, whose economic and environmental resilience against market shocks has significantly 
improved due to the increased diversity of crops grown. By diversifying crops, the farmers' dependence on external outputs dropped significantly [47].

\subsection{Agricultural Inputs Used After the Adoption of Permaculture}

As an organic system, permaculture refrains from the use of synthetic fertilizers and pesticides. It promotes the use of available resources for this purpose. This is noted in the fifth principle, use and value renewable resources. In both South Africa and Zimbabwe, participants switched from using chemical to organic fertilizers/pesticides and from hybrid to non-hybrid seeds.

From an environmental point of view, the use of biological fertilizers, such as green manure, increases soil fertility [48]. This has also been observed in Malawi, where the use of organic fertilizers improved soil fertility [49]. This may lead to stability and effective production cycles, which can increase soil organic carbon and fertility, resulting in less soil erosion and greater soil biodiversity. Another example of this is seen in the use of animal manure or legumes (nitrogen fixing plants) instead of mineral nitrogen fertilizer. The benefits of using legumes and animal manure have been shown to outweigh those of mineral nitrogen fertilizers, which contribute $40 \%-60 \%$ to farm energy demand [50]. Pimentel et al. (2005) note that systems that use animal manure and legumes show higher yield resilience to drought [51]. However, if legumes are solely used to replace fertilizers, the efficiency of the land may decrease [49].

Generally, permaculture systems are cost effective, due to the reduced use of chemical inputs. This is especially important for resource-poor farmers. Proponents of permaculture argue that the use of inexpensive biological resources improves productivity and conserves the environment [32,49,52]. Although permaculture can be effective in delivering high environmental benefits, major challenges include lower yields and higher labour input than in conventional agriculture [53].

\subsection{Environmental Benefits and Challenges}

As seen in Table 4, a major benefit associated with permaculture is long term environmental sustainability and resilience. Participants in both South Africa and Zimbabwe stated that permaculture helped them address environmental problems and climate change. This can be linked to the type of agricultural inputs used, as discussed in the previous section. The use of organic inputs was found to increase soil fertility and moisture retention, which helps improve the drought resistance of crops [54].

Tirado and Cotter (2010) explain the practical methods of using organic inputs. An example of this is through the use of manure and legume intercrops, which is an example of integration, principle eight of permaculture [55]. This enhances soil structure, which increases its water infiltration and retention capacity, and, thus, lessens the risks of drought. The reduction of chemical inputs fosters respect for the environment which is one of the core ethics of permaculture, care for the Earth, and also one that improves the agro-environment.

Despite Tirado and Cotter (2010)'s findings, consecutive years of drought posed significant challenges to both South African and Zimbabwean participants. This was a recurring theme, as both countries are typically vulnerable to seasonal droughts, which may be detrimental to food production. Wheeler and Von Braun (2013) suggest that crop yields across Africa will decrease in future as a result of climate change, making it one of the most vulnerable continents. This reinforces the need to shift towards practices that help farmers improve soil moisture retention [56].

Another challenge faced by South African and Zimbabwean respondents was the infestation of pests and diseases. As seen in Figure 5, the majority of respondents from both countries switched from chemical to organic pesticides. Growing toxic and insect repellent plants was also used as a method to deter pests. Although several studies have identified the potential of crop diversification for pest control, our study revealed pest and disease control as a challenge to practitioners. Bahlai et al. (2010) state that organic pesticides may not always represent the best solution for pest control. They also note that a cautionary approach must be adopted, especially when introducing novel organisms to fight pests [57]. In certain instances, the introduction of allied insects can result in more harm than 
synthetics [58]. This, in turn, can have negative effects on yields and, consequently, on livelihoods. An understanding of local conditions is, thus, crucial in developing appropriate systems that are effective.

\subsection{Health Benefits and Challenges}

Particularly relevant to permaculture is the importance of agrobiodiversity for improved food security and health [59]. Similarly, participants in our study mentioned health benefits associated with permaculture, such as having access to more diverse food. Müller and Krawinkel (2005) found that community-based gardening interventions in Southern Africa improved nutrition at household and community levels, by enabling direct access to and increasing consumption of fruits and vegetables [60].

A recent study carried out in Uganda by Namululi (2011) concluded that those who practise permaculture are more food secure than those who do not [61]. In contrast, a study conducted in Malawi showed that small-scale permaculture use has a limited positive impact on food security [29]. Rather than substantially changing household food security status, permaculture enables consistent access to food annually. This may create a nutrition buffer to ensure that households have complementary food when needed [61,62]. It is imperative to note that food security is impacted by broader factors, such as food availability, market prices, and many more. This affects households in different ways. Further studies are therefore required to assess the role of permaculture in addressing food security.

\subsection{Economic Benefits and Challenges}

Reducing external inputs was the most important economic advantage associated with permaculture. Following this, the ability of permaculture systems to produce high yields was another advantage. A study conducted by Nemes (2009) showed that organic agriculture was responsible for higher profitability due to higher yields and reduced costs [63]. A similar trend was found in a study conducted in Quebec [64]. The study revealed that partial income from produce can increase the profitability of permaculture.

Decreased efficiency in terms of low yields and high labour input were challenges that both South African and Zimbabwean participants faced. Although low inputs presented an opportunity for practitioners to save money, Seufert et al. (2012) argue that such techniques can be less productive, less efficient, and not economically competitive [65]. Baudron et al. (2012) assert that low external input techniques can be inappropriate for labour and resource constrained farmers in Southern Africa [66]. They also state that adoption of these techniques may be too difficult or risky if not executed with expertise. On the other hand, van Elzakker and Eyhorn (2010) propose that the labour-intensive nature of permaculture can increase employment opportunities in rural areas [67]. However, there has not been enough research on permaculture to evaluate its impact or application on a large scale [11].

\subsection{Educational Challenges}

Lack of knowledge on addressing problems using permaculture practices was a challenge many South African practitioners faced (Table 5). Given that permaculture is a knowledge intensive system, accessing and acquiring knowledge is important [49]. In developing countries, small-scale farmers may adopt permaculture because it integrates traditional and indigenous knowledge practices $[52,68]$. Small-holder farmers are usually neglected in research policies. It is crucial to improve access to knowledge to improve farmers' livelihoods.

\section{Conclusions}

Permaculture can be effective in supporting multiple objectives. As revealed in this study, permaculture may help support livelihood activities and improve the ability of farmers to deal with environmental problems. It also holds the key to increasing dietary diversity within households and enhancing social and ecological resilience. However, as with any agricultural system, it has its limitations. While permaculture on its own may not match the yields produced through conventional 
techniques, the prudent path towards reforming the global food system will require holistic approaches that have a neutral environmental effect and are economically viable.

This implies a transition from conventional, monoculture-based, and intensive production towards an array of sustainable regenerative production systems that improve productivity. Furthermore, shifting from a linear to a holistic approach in agricultural management is necessary. An approach that acknowledges the role of people as not mere producers of food, but also as managers of ecological systems that produce a suite of ecosystem services is needed.

A necessary step for this will require institutional support that favours transitions across all stages of food systems, which includes improving the resilience of rural livelihoods. A space for knowledge exchange on sustainable agricultural practices, coupled with a supporting environment and strong governance are also vital. This entails a strong emphasis on alternative agricultural practices in national strategies. Lastly, increasing funds to support such transitions will be required from community to national levels in order to advance socio-economic development.

Author Contributions: Authors contributed equally to the work reported.

Funding: This research was funded by the Department of Environmental Science, Rhodes University.

Acknowledgments: I would like to express my sincere gratitude to my supervisor, James Gambiza and my co-supervisor, Rebecca Powell for their continuous support and guidance. I would also like to thank Hope Permaculture and CELUCT for recommending enumerators and key informants. Lastly I would like to thank my family for their unconditional support throughout all stages of this research.

Conflicts of Interest: The authors declare no conflict of interest.

\section{Appendix A. Principles of Permaculture}

Table A1. Summary of permaculture principles with examples.

\begin{tabular}{ll}
\hline Principle & Examples \\
\hline I. Observe and Interact & Adaptive management \\
\hline II. Catch and Store Energy & $\begin{array}{l}\text { Organic mulch application } \\
\text { Rainwater harvesting measures }\end{array}$ \\
\hline III. Obtain a Yield & Ecosystem services concept \\
\hline IV. Apply Self-Regulation and Accept Feedback & Enhancement of regulating ecosystem services \\
\hline V. Use and Value Renewable Resources and Services & Natural habitats in agricultural landscapes \\
\hline VI. Produce no Waste & Legumes and animal manure as nutrient source \\
\hline VII. Design from Patterns to Details & Animal manure \\
\hline VIII. Integrate Rather than Segregate & Waste products as animal feed \\
\hline IX. Use Small and Slow Solutions & Natural ecosystem mimicry \\
\hline X. Use and Value Diversity & Polyculture (crops) \\
& Inverse productivity-size relationship \\
& $\begin{array}{l}\text { Plant species diversity } \\
\text { Pollinator diversity }\end{array}$ \\
\hline XI. Use Edges and Value the Marginal & Habitat diversity \\
\hline XII. Creatively Use and Respond to Change & Diversified farming systems \\
\hline
\end{tabular}




\section{Appendix B. Additional Results}

Table A2. Chi-square tests on change in income after practising permaculture, across South African and Zimbabwean respondents.

\begin{tabular}{lccl}
\hline & South Africa $(\boldsymbol{n}=\mathbf{4 4})$ & Zimbabwe $(\boldsymbol{n}=\mathbf{5 0 )}$ & $\chi^{\mathbf{2}}$ \\
\hline Slightly & 15 & 25 & 2.50 \\
Moderately & 7 & 14 & 2.33 \\
Substantially & 14 & 9 & 1.09 \\
No change & 8 & 2 & 3.6 \\
$\chi^{2}$ & 4.55 & $22.48^{* * *}$ & \\
\hline
\end{tabular}

Table A3. Paired Wilcoxon values $(V)$ of average number of crops grown before and after practising permaculture.

\begin{tabular}{lcc}
\hline Crop Variety & South Africa & Zimbabwe \\
\hline Cereals & 30 & $103^{*}$ \\
Legumes & $45^{*}$ & $539^{* * *}$ \\
Vegetables & $507^{* * *}$ & $527.5^{* * *}$ \\
Fruits & $325^{* * *}$ & $225^{* * *}$ \\
Tubers & 53 & $322.5^{* * *}$ \\
\hline \multicolumn{3}{r}{$* 0.05,{ }^{* * *} p<0.001}$.
\end{tabular}

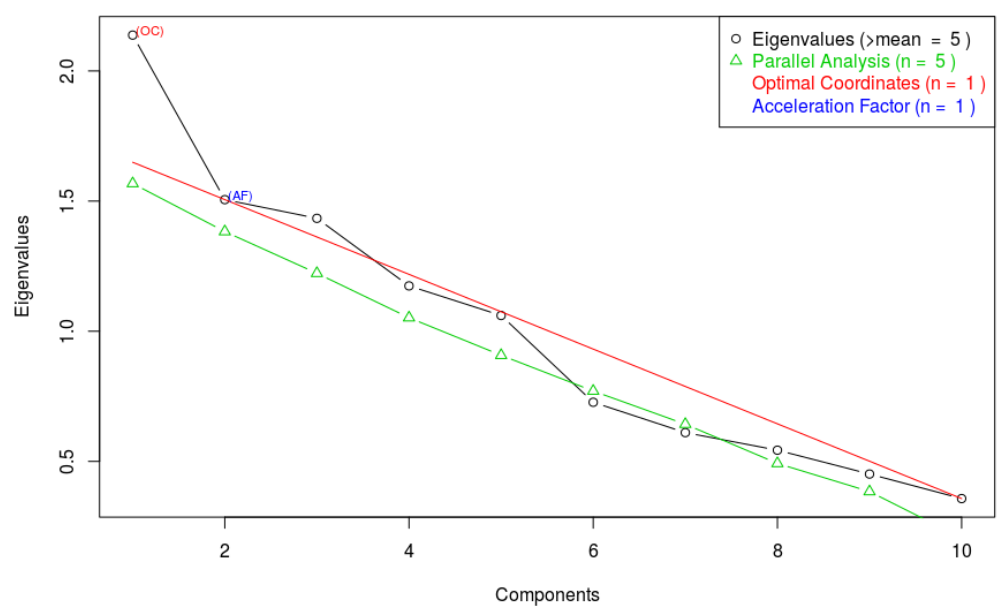

Figure A1. Scree plot used to determine the optimum number of factors required for South African data.

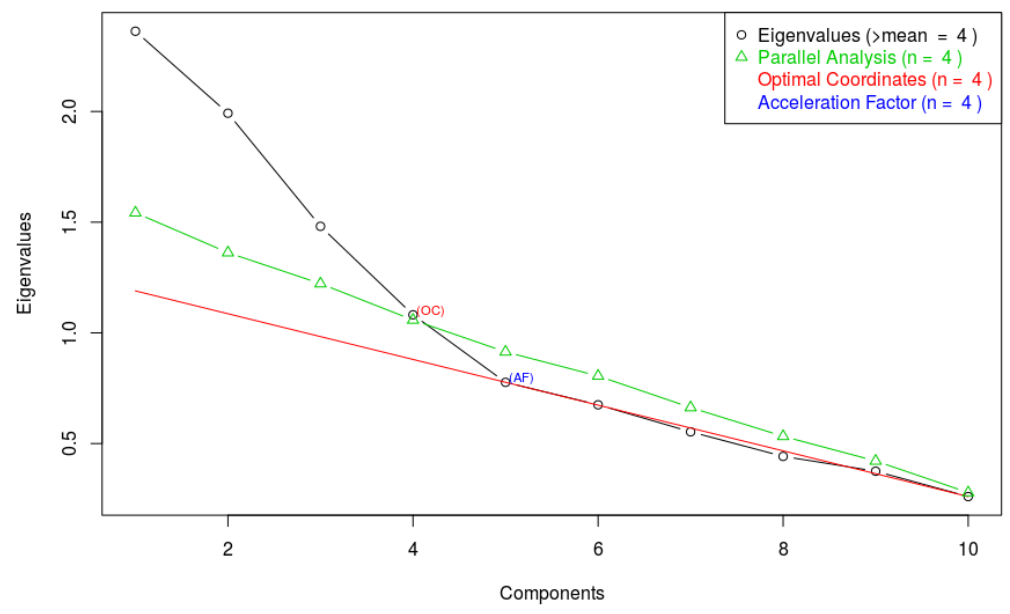

Figure A2. Scree plot used to determine the optimum number of factors required for Zimbabwean data. 


\section{References}

1. Pimentel, D. Food for Thought: A Review of the Role of Energy in Current and Evolving Agriculture. Crit. Rev. Plant Sci. 2011, 30, 35-44. [CrossRef]

2. Thrall, P.H.; Bever, J.D.; Burdon, J.J. Evolutionary change in agriculture: the past, present and future. Evol. Appl. 2010, 3, 405-408. [CrossRef] [PubMed]

3. Altieri, M.A.; Nicholls, C.I. The adaptation and mitigation potential of traditional agriculture in a changing climate. Clim. Chang. 2017, 140, 33-45. [CrossRef]

4. UN Environment. Global Environment Outlook-6 (GEO-6). Healthy Planet Healthy People 2019, 34-37. [CrossRef]

5. Gomiero, T.; Pimentel, D.; Paoletti, M.G. Is There a Need for a More Sustainable Agriculture? Crit. Rev. Plant Sci. 2011, 30, 6-23. [CrossRef]

6. Wang, H.H. Agricultural risks and risk management in the current context of Chinese economy. Agric. Financ. Rev. 2013, 73, 245-254. [CrossRef]

7. FAO. Food and Agriculture Organization of the United Nations; FAO Publications Catalogue 2017: Rome, Italy, 2017.

8. Greenblott, K.; Nordin, K. Permaculture Design for Orphans and vulnerable children programming. Low-Cost Sustainable Solutions for Food and Nutrition Insecure Communities; United States Agency for International Development: Washington, DC, USA, 2012.

9. Sayer, J.; Sunderland, T.; Ghazoul, J.; Pfund, J.L.; Sheil, D.; Meijaard, E.; Venter, M.; Boedhihartono, A.K.; Day, M.; Garcia, C.; et al. Ten principles for a landscape approach to reconciling agriculture, conservation, and other competing land uses. Proc. Natl. Acad. Sci. USA 2013, 110, 8349-8356. [CrossRef]

10. Mollison, B. Permaculture: A Designer's Manual; Tagari Publications: Sisters Creek, Australia, 1988.

11. Ferguson, R.S.; Lovell, S.T. Permaculture for agroecology: design, movement, practice, and worldview. A review. Agron. Sustain. Dev. 2014, 34, 251-274. [CrossRef]

12. Holmgren, D. Permaculture: Principles E Pathways Beyond Sustainability; Holmgren Design Services: Hepburn, Victoria, Australia, 2002.

13. Krebs, J.; Bach, S. Permaculture-Scientific Evidence of Principles for the Agroecological Design of Farming Systems. Sustainability 2018, 10, 3218. [CrossRef]

14. Francis, C.A.; Porter, P. Ecology in sustainable agriculture practices and systems. Crit. Rev. Plant Sci. 2011, 30, 64-73. [CrossRef]

15. Leakey, R.R.B. Multifunctional Agriculture and Opportunities for Agroforestry: Implications of IAASTD. In Agroforestry - The Future of Global Land Use; Nair, P.R., Garrity, D., Eds.; Springer Netherlands: Dordrecht, The Netherlands, 2012; pp. 203-214._13. [CrossRef]

16. Mononen, L. Systems thinking and its contribution to understanding future designer thinking. Des. J. 2017, 20, S4529-S4538. [CrossRef]

17. Farrelly, M. Agroecology Contributes to the Sustainable Development Goals; ILEIA: Rome, Italy, 2017.

18. Kruger, E. Cultivating natures: movements in South African permaculture. Ph.D. Thesis, University of the Witwatersrand, Johannesburg, South Africa, 2017.

19. Amathole Municipality. DISTRICT FRAMEWORK FOR 2015-2016 IDP REVIEW; Technical Report; The Executive Mayor: East London, South Africa, 2016.

20. Nkonkobe Municipality. DISTRICT FRAMEWORK FOR 2008-2009 IDP REVIEW; Technical Report; The Executive Mayor: Alice, South Africa, 2009.

21. OR Tambo District. INTEGRATED DEVELOPMENT PLAN (IDP) 2017-2022; Technical Report; The Executive Mayor: Mthatha, South Africa, 2017.

22. Wills, J.; Chinemana, F.; Rudolph, M. Growing or connecting? An urban food garden in Johannesburg. Health Prom. Int. 2010, 25, 33-41. [CrossRef]

23. Mashapa, C.; Zisadza-Gandiwa, P.; Gandiwa, E.; Kativu, S. Abundance and structure of African Baobab (Adansonia digitata) across different soil types in Gonarezhou National Park, Zimbabwe. Int. J. Biodivers. 2013, 2013. [CrossRef]

24. Creswell, J.W.; Klassen, A.C.; Plano Clark, V.L.; Smith, K.C. Best Practices for Mixed Methods Research in the Health Sciences; National Institutes of Health: Bethesda, MD, USA, 2011. 
25. Rhodes University. Rhodes University Ethical Standards Committee Handbook. 2014. Available online: http:/ / www.ru.ac.za/media/rhodesuniversity/content/ethics/RUESC_Handbook_\%202014-11-21_v\% 201.01.pdf (accessed on 13 October 2018).

26. RStudio Team. RStudio: Integrated Development Environment for R; RStudio, Inc.: Boston, MA, USA, 2015.

27. Kim, S.E.; Seo, I.W.; Choi, S.Y. Assessment of water quality variation of a monitoring network using exploratory factor analysis and empirical orthogonal function. Environ. Model. Softw. 2017, 94, 21-35. [CrossRef]

28. Kline, P. An Easy Guide to Factor Analysis; Routledge: Abingdon, UK, 2014.

29. Conrad, A. We are Farmers: Agriculture, Food Security, and Adaptive Capacity Among Permaculture and Conventional Farmers in Central Malawi. Ph.D. Thesis, American University, Washington, DC, USA, 2014.

30. Lee, E.; Krasny, M.E. The role of social learning for social-ecological systems in Korean village groves restoration. Ecol. Soc. 2015, 20. [CrossRef]

31. Torralba, M.; Fagerholm, N.; Burgess, P.J.; Moreno, G.; Plieninger, T. Do European agroforestry systems enhance biodiversity and ecosystem services? A meta-analysis. Agric. Ecosyst. Environ. 2016, 230, 150-161. [CrossRef]

32. UNCTAD. UNCTAD. Wake up before it is too late. In Proceedings of the United Nations Conference on Trade and Development (UNCTAD), Geneva, Switzerland, 16-27 September 2013.

33. Lowder, S.K.; Skoet, J.; Raney, T. The Number, Size, and Distribution of Farms, Smallholder Farms, and Family Farms Worldwide. World Dev. 2016, 87, 16-29. [CrossRef]

34. Ferguson, R.S.; Lovell, S.T. Livelihoods and production diversity on U.S. permaculture farms. Agroecol. Sustain. Food Syst. 2017, 41, 588-613. [CrossRef]

35. Ali, D.A.; Deininger, K. Is There a Farm-Size Productivity Relationship in African Agriculture? Evidence from Rwanda; The World Bank: Washington, DC, USA, 2014.

36. Batáry, P.; Gallé, R.; Riesch, F.; Fischer, C.; Dormann, C.F.; Mußhoff, O.; Császár, P.; Fusaro, S.; Gayer, C.; Happe, A.K.; et al. The former Iron Curtain still drives biodiversity-profit trade-offs in German agriculture. Nat. Ecol. Evol. 2017, 1, 1279. [CrossRef] [PubMed]

37. FAO. Agriculture in Sub-Saharan Africa:Prospects and Challenges for the Next Decade; FAO Publications Catalogue 2016: Rome, Italy, 2016.

38. Tererai, F. The effects of invasive trees in riparian zones and implications for management and restoration: Insights from Eucalyptus invasions in South Africa. Ph.D. Thesis, Stellenbosch University, Cape Town, South Africa, 2012.

39. Rodriguez, J.; Molnar, J.; Fazio, R.; Sydnor, E.; Lowe, M. Barriers to adoption of sustainable agriculture practices: Change agent perspectives. Renew. Agric. Food Syst. 2009, 24, 60-71. [CrossRef]

40. Falk, B. The Resilient Farm and Homestead: An Innovative Permaculture and Whole Systems Design Approach; Chelsea Green Publishing Company: Chelsea, VT, USA, 2013.

41. Zimmerer, K. Biological Diversity in Agriculture and Global Change. Annu. Rev. Environ. Resour. $2010,35$. [CrossRef]

42. Shepard, M. Restoration Agriculture: Real-world Permaculture for Farmers; Acres U.S.A.: Greeley, CO, USA, 2013.

43. Chapoto, A.; Jayne, T.S. The Impacts of Trade Barriers and Market Interventions on Maize Price Predictability: Evidence from Eastern and Southern Africa; Technical Report; Michigan State University, Department of Agricultural, Food, and Resource Economics: East Lansing, MI, USA, 2009.

44. De Clerck, F.A.; Fanzo, J.; Palm, C.; Remans, R. Ecological approaches to human nutrition. Food Nutr. Bull. 2011, 32, S41-S50. [CrossRef]

45. Remans, R.; Flynn, D.F.; DeClerck, F.; Diru, W.; Fanzo, J.; Gaynor, K.; Lambrecht, I.; Mudiope, J.; Mutuo, P.K.; Nkhoma, P.; ; et al. Assessing nutritional diversity of cropping systems in African villages. PLoS ONE 2011, 6, e21235. [CrossRef]

46. Buck, O.; Niyogi, D.K.; Townsend, C.R. Scale-dependence of land use effects on water quality of streams in agricultural catchments. Environ. Pollut. 2004, 130, 287-299. [CrossRef]

47. Bonaudo, T.; Bendahan, A.B.; Sabatier, R.; Ryschawy, J.; Bellon, S.; Leger, F.; Magda, D.; Tichit, M. Agroecological principles for the redesign of integrated crop-livestock systems. Eur. J. Agron. 2014, 57, 43-51. [CrossRef]

48. Morshedi, L.; Lashgarara, F.; Farajollah Hosseini, S.J.; Omidi Najafabadi, M. The Role of Organic Farming for Improving Food Security from the Perspective of Fars Farmers. Sustainability 2017, 9, 2086. [CrossRef] 
49. De Schutter, O. Report on Agroecology and the Right to Food; 16th Session of the United Nations Human Rights Council [A/HRC/16/49], UN: Geneva, Switzerland, 2013.

50. Mudahar, M.S.; Hignett, T. Energy requirements, technology and resources in the fertilizer sector. Energy Plant Nutr. Pest Control Energy World Agric. 1987, 2, 25-61.

51. Pimentel, D.; Hepperly, P.; Hanson, J.; Douds, D.; Seidel, R. Environmental, Energetic, and Economic Comparisons of Organic and Conventional Farming Systems. BioScience 2005, 55, 573-582. [CrossRef]

52. FAO. FAO'S WORK ON AGROECOLOGY; FAO Publications Catalogue 2018: Rome, Italy, 2018.

53. Jouzi, Z.; Azadi, H.; Taheri, F.; Zarafshani, K.; Gebrehiwot, K.; Van Passel, S.; Lebailly, P. Organic farming and small-scale farmers: Main opportunities and challenges. Ecol. Econ. 2017, 132, 144-154. [CrossRef]

54. Bhardwaj, D.; Ansari, M.W.; Sahoo, R.K.; Tuteja, N. Biofertilizers function as key player in sustainable agriculture by improving soil fertility, plant tolerance and crop productivity. Microb. Cell Factor. 2014, 13, 66. [CrossRef]

55. Tirado, R.; Cotter, J. Ecological Farming: Drought-Resistant Agriculture; Greenpeace Research Laboratories: Exeter, UK, 2010.

56. Wheeler, T.; Von Braun, J. Climate change impacts on global food security. Science 2013, 341, 508-513. [CrossRef] [PubMed]

57. Bahlai, C.A.; Xue, Y.; McCreary, C.M.; Schaafsma, A.W.; Hallett, R.H. Choosing organic pesticides over synthetic pesticides may not effectively mitigate environmental risk in soybeans. PLoS ONE 2010, 5, e11250. [CrossRef]

58. Elliot, S.L.; Mumford, J.D. Organic, integrated and conventional apple production: why not consider the middle ground? Crop Prot. 2002, 21, 427-429. [CrossRef]

59. Frison, E.A.; Cherfas, J.; Hodgkin, T. Agricultural Biodiversity Is Essential for a Sustainable Improvement in Food and Nutrition Security. Sustainability 2011, 3, 238-253. [CrossRef]

60. Müller, O.; Krawinkel, M. Malnutrition and health in developing countries. Can. Med. Assoc. J. 2005, 173, 279-286. [CrossRef] [PubMed]

61. Namululi, A. The Potential of Permaculture in AddressingFood Insecurity in Karamoja District, Uganda. Ph.D. Thesis, Uppsala University, Uppsala, Sweden, 2011.

62. Altman, M.; Hart, T.G.; Jacobs, P.T. Household food security status in South Africa. Agrekon 2009, 48, 345-361. [CrossRef]

63. Nemes, N. Comparative Analysis of Organic and Non-Organic Farming Systems: A Critical Assessment of Farm Profitability; FAO: Rome, Italy, 2009.

64. Bastien, G. Permaculture-Inspired Farms in Quebec: An Economic and Social Overview. Master's Thesis, Harvard University, Cambridge, MA, USA, 2016.

65. Seufert, V.; Ramankutty, N.; Foley, J.A. Comparing the yields of organic and conventional agriculture. Nature 2012, 485, 229. [CrossRef]

66. Baudron, F.; Tittonell, P.; Corbeels, M.; Letourmy, P.; Giller, K.E. Comparative performance of conservation agriculture and current smallholder farming practices in semi-arid Zimbabwe. Field Crops Res. 2012, 132, 117-128. [CrossRef]

67. van Elzakker, B.; Eyhorn, F. The Organic Business Guide: Developing Sustainable Value Chains with Smallholders; The Organic Business Guide, The International Federation of Organic Agriculture Movements: Bonn, Germany, 2010.

68. Oniang'o, R.K.; Mutuku, J.M.; Malaba, S.J. Contemporary African food habits and their nutritional and health implications. Asia Pac. J. Clin. Nutr. 2003, 12, 231-236.

(c) 2019 by the authors. Licensee MDPI, Basel, Switzerland. This article is an open access article distributed under the terms and conditions of the Creative Commons Attribution (CC BY) license (http://creativecommons.org/licenses/by/4.0/). 